\title{
Educational Acpects in Environmental Problem in Indonesia
}

\author{
Mortaza A Syafinuddin Hammada ${ }^{1}$ \\ dinmandar@gmail.com \\ ${ }^{1}$ Lecturer of The Faculty of Engineering, Cokroaminoto University of Makassar and Member \\ Indonesia of Indonesian Environmental Scientist Association (IESA)
}

\begin{abstract}
Sustainability is an important topic in environmental studies. All country agree on sustainable development. In addition, special studies are need to look at educational factors in environmental studies. The Indonesian Government now have a program to build an environmental awareness in the school, namely Adiwiyata. In fact, the influence of the program is very low. Therefore, the objective of the research is to find and describe the perspective of educational aspect in the environmental problem in Indonesia. This study use qualitative research method (grounded research and phenomenology research). The study is use purposive sampling method. During two year of this research, it was found that the main environmental problem in Indonesia were knowledge and awareness. Education is no longer interpreted as formal process of knowledge transfer in existing educational institutional. Education have to change immediately into a cultural transformation, and needs to be expanded to reach various sectors.
\end{abstract}

Keywords: Environmental education; Environmental culture; Adiwiyata.

\section{Introduction}

The world's attention to environmental issues has been long enough. Various concept agreed at the head of state meeting since World Summit June 5, 1972, in Stockholm, Sweden. The whole world even agreed on June 5 as the World Environment Day. This is to encourge the citizens of the world to have increasingly advanced environmental awareness every year. Twenty years later, the United Nation introduce a document called Agenda 21. The Agenda 21 is a declaration accepted by the head of the state in the Earth Summit held at Rio De Jeneiro, Brazil, 1992. The document introduce the concept of how to implement the sustainable development with a systematic plan. (Selman \& Parker, 2007). This concept has been emphasize by various countries as one of the considerations in each policy. Indonesia is a country that includes environmental aspects in various official regulations.

Along with the progress of the development program, there are still many cases of the environmental damages, even though the government issued some regulations regarding environmental protection and preservation. Therefore, it need strong effort to find the problem solving all of those cases. Theoretically, the concept used to solve these problems are 
environmental management and environmental engineering. The interrelation between various parties in environmental management also influences the successful resolution of environmental problems. (Groffman et.al., 2006). Likewise, the principle of inseparability between nature and humans should be an accepted part of the most important part of ecological engineering. (Bergen et.al., 2001).

Environmental management is the concept of developing of protection and prevention that expected to overcome the weakness of handling existing environmental problem. This concept, carry out simultaneously from the planning to evaluation program stages. Environmental management presented to meet the demands of integrated protection involving all sectors. The concept of environmental management starts with the ability to identify environmental problems more thoroughly. Environmental problems that can identified will produce the best plans to protect and preserve the environment. (Dreyfus, 1970).

The environmental management progress given a big change in many policies but occasionally failed in change an affective dimension of public acts. The environmental management are all of the management aspects that have relation with the environmental policy. (Sturm, 1998). What was Sturm emphasized just for policies need.

The fundamental of environmental management is closed relationship to the educational aspects. (Roth, 1970). It means what are we create for making good environment condition must effected to the shifting citizens behavior. Therefore, the environmental management has relation to the public education to change their awareness.

The latest document that confirms the world commitment to environmental preservation is the Sustainable Development Goals (SDGs). This commitment states that in 2015 all countries have provided effort to eliminate poverty and hunger, education for all, gender equality and empowerment of women, reducing child mortality, improving maternal health, resisting various infectious diseases, preserving the environment, and global cooperation to progress. One of SDGs indicators is education for all. It means the education factors is a very important to point for sustainability vision as well as environmental perspectives.

This concept has shown a serious idea about the importance of sustainability and efforts to prevent the impact of environmental damage. SDGs have indicators that are attached to; human development, namely education and health; socio-economic environment, namely facilities and pre-facilities and economic growth; development of the physical environment (environment development), namely the availability of natural resources and good environmental quality. Both human development and environmental development as a part of SDGs indicators are basis of environmental principles. The Indonesian government has developed the principles of sustainable development through the concept of Education for Sustainable Development. This program is expect to be able to leverage environmental awareness in a wider area. School influence is highly expected in the program.

Environmental education will strengthen the conventional education system so that it can foster the ability to make policies about environmental literacy in the classroom. For this, David T. G. (1974) explains as follows:

"Environmental education, in most contemporary educational practice, amounts to nothing more than a revitalized form of conservation education. The natural environment and its preservation serve as convenient outlets into which the subject matter of the more conventional sciences are plugged. Some have extended the concept to the built/urban environment and its social aspects, with considerable success. But the possibilities and process of making decisions about the structure of the environment are of central importance. If the physical setting does affect the inhabitants of classrooms, it is logical, if not essential, to begin the exploration of environmental literacy with the classroom itself and the dimensions of its influence." 
Environmental education also related to changes in culture or social character. Culture will formed with a habituation process. Habit will be more effective if carried out in a systematic, measurable, and sustainable program in educational institutions. Cultivation can strengthen environmental awareness and the concept of sustainability. The concept of environmental education is perform a tasks affectively, that is vital that the citizenry be knowledgeable concerning their biophysical environment and associated problem, aware of how they can help solve their problems, and motivated to work toward affective solution. (Stapp, 1969). Environmental education is a transfer of knowledge, aware, and skill to preserve and protect the environment resources.

The Indonesian government has launch a program as a part of an environmental education, through the Ministry of Environment in collaboration with the Ministry of Education and Culture. The program namely Adiwiyata. Adiwiyata consist of two word; ADI mean great, and WIYATA means the place for everyone to get knowledge, norm and ethics for their social life. So, Adiwiyata is defined as the best and ideal place where everybody to get knowledge, norm, and ethics values to be base of human life toward welfare society and manifested the sustainable development vision.

During 13-year the program after launched, Adiwiyata schools has brought several changes, including the habit of saving energy, processing and utilizing waste, saving water, awareness of tree functions and vegetation in nature, and so on. These achievements bring hope, especially to foster the habits and culture of the environment of the school community.

After 13 years, the program showed different results. Not only concerning to the ability of schools to maintain their achievements (Adiwiyata Award), but also the influence of program outside of school. Many schools that cannot continue to care for the environment. However many schools can maintain their environmental culture because of adiwiyata programs, but those are still limited in the school environment.

The transfer of knowledge about the environment cannot guarantee a change in behavior to be more environmentally friendly. Similar to the implementation of the systematically designed programs, such as the Adiwiyata. On the other hand, many people apply the principles of environmentally friendly in their daily lives. This shows that there are problems in the process of environmental education in Indonesia, even the concepts and perspectives.

Thus, it is necessary to search for new perspectives on environmental education that are reliable for changing human behavior. Therefore, this study aims to explain the gap between expectations for environmental education programs and the facts of environmentally friendly behavior in Indonesia, as well as to build a new perspective on environmental education.

Based on these reason, the temporary conjecture that functions as a working hypothesis in this study is that the understanding of education has been very narrow and limited to the process of interaction in classrooms. Therefore, environmental education is less functioning to transform environmentally conscious behavior, especially in the wider community.

\section{Method}

The research method is qualitative research. The design of this study consisted of two groups of informants. The grouping is based on purposive sampling. The first group are people who have implemented an environmentally conscious life, while the second group is the opposite. The indicators are a culture of energy saving, water saving, sensitivity to pollution, 
concern for the effects of waste and efforts to overcome it, initiatives to carry out engineering to overcome environmental problems, and so on.

This study uses observation guidelines about the facts of environmentally conscious behavior, open interviews that ask the reasons for applying or not applying environmental principles, as well as tracing their relationship with education. The last stage was conducting FGD with five experts and environmental practitioners to create a new perspective on environmental education.

This research was carried out for four years, September 2011 to September 2013 in South Jakarta. The location of this research is SD Ciganjur Elementary School as one of the Adiwiyata Mandiri award-winning schools and SDN No. No. residents. 6 Cilandak Barat, South Jakarta. This research is to explain the environmentally conscious behavior of school residents in both places. Furthermore, the research was further developed to look at the environmentally conscious behavior of residents around the school who gained knowledge about the environment through curricular programs in schools with residents who obtained inspiration from other sources. This research development was carried out for one year, January 2017 to January 2018 at the same location (Ciganjur dan Cilandak Barat).

\section{Result and Discussion}

The categories of Adiwiyata school development seen from the culture of environmental awareness are three, namely; influencing out of school, only developing within the school area, failing to maintain environmental culture. Based in observations of SD Alam Ciganjur, school predicated on Adiwiyata Mandiri for year 2009, information was obtained that only five percent of them could have a positive influence on community around the school, even ninety five percent of them failed to maintain cultural behavior in their communities.

Interviews conducted to several informants proved that habituation that was only done to deal with certain events, including the Adiwiyata assessment, would cause the process to be unsustainable. That is, it is likely that it will fail to continue and give birth to a culture of environmental awareness.

By comparing between schools that apply Adiwiyata's principles and indicators with those who have not one, both of them are differences. Knowledge and environmental insights from school residents who apply Adiwiyata criteria are better than those who do not apply them. However, over time, there is a tendency that these habits cannot survive and as a culture of the school community as a whole. Likewise, the effect on the culture of the community outside or around the school.

However, if it is implemented in a long period of time, it is very possible that changes will occur because Adiwiyata meets Education for Sustainable Development (ESD). ESD has been tried in several places and proven successful, for example in Banjarmasin, South Kalimantan. The findings of this study indicate that the Adiwiyata concept contains the ESD criteria. The following is a comparison of the Adiwiyata concept with ESD.

Table 1. Conception relation between ESD and Adiwiyata 


\begin{tabular}{|c|c|c|}
\hline No. & ESD Criteria & Adiwiyata Indicators \\
\hline 1. & Learner centered. & $\begin{array}{l}\text { “... student center." (Adiwiyata } \\
\text { Guideline Book, 2011) }\end{array}$ \\
\hline 2. & $\begin{array}{l}\text { Interdisciplinary and } \\
\text { holistic education }\end{array}$ & $\begin{array}{l}\text { "Integrated learning between } \\
\text { environmental subject and } \\
\text { others, insides the monolithic } \\
\text { one." (Adiwiyata Guideline } \\
\text { Book, 2011) }\end{array}$ \\
\hline 3. & $\begin{array}{l}\text { Multi approaches, } \\
\text { variety, and method } \\
\text { education }\end{array}$ & $\begin{array}{l}\text { "Implementing varieties learning } \\
\text { methods focused on learner } \\
\text { (learner centered) according to } \\
\text { their needs." (Adiwiyata } \\
\text { Guideline Book, 2011) }\end{array}$ \\
\hline 4. & $\begin{array}{l}\text { Based on systemic } \\
\text { approach education. }\end{array}$ & $\begin{array}{l}\text { "Exploring, encouraging, and } \\
\text { developing materials and } \\
\text { environmental problems in the } \\
\text { society." } \\
\text { "Public participation and } \\
\text { partnership in the concept of } \\
\text { quality development." } \\
\text { (Adiwiyata Guideline Book, } \\
\text { 2011) }\end{array}$ \\
\hline 5. & Encourages the values & $\begin{array}{l}\text { There is a norm and ethics } \\
\text { education in the spirit of } \\
\text { Adiwiayata as well. ." } \\
\text { (Adiwiyata Guideline Book, } \\
\text { 2011) }\end{array}$ \\
\hline 6. & $\begin{array}{l}\text { Using te local culture } \\
\text { approach, local issues } \\
\text { besides global issues, } \\
\text { and understanding } \\
\text { meanings for all } \\
\text { parties/stakeholders. }\end{array}$ & $\begin{array}{l}\text { "Local wisdom and cultural } \\
\text { values utilizing in environmental } \\
\text { learneing."." (Adiwiyata } \\
\text { Guideline Book, 2011) }\end{array}$ \\
\hline 7. & Long life learning & $\begin{array}{l}\text { All of the school citizens are } \\
\text { well inform on vision, mission, } \\
\text { and the aims of the } \\
\text { environmental insight school. } \\
\text { All of them are taking a part in } \\
\text { responsibility on realializing the } \\
\text { environmental culture education } \\
\text { together." (Adiwiyata Guideline } \\
\text { Book, 2011) }\end{array}$ \\
\hline
\end{tabular}

Source: Hammada (2015) 
Based on the findings of the above research, if it assumed that the condition of each school in Indonesia is the same as the school sample observed in this study, it is probable that the expected outcomes of the Adiwiyata program will not be optimal enough. Of course, other research still needed that considers other factors and variables to get more accurate information and analysis. However, it can concluded that educational factors are very influential in raising awareness of environmental protection and preservation. Habituation in the process of environmental education requires considerable time because it involves changes in knowledge, attitudes, and awareness and human behavior in it.

Experience in the Adiwiyata program, choosing environmental education must not only be interpreted as a program approved by educational institutions. Environmental education received is interpreted as a way to inspire people to be able to grow environmental awareness in themselves.

If all environmental engineering designs use devices that can be seen by the community as designs intended for natural and social resources, then the community will gain a new perspective on environmental management. Similarly, the policies governing the concept of environmental management. If he manages to be seen as deliberate by collecting policies to protect the environment, then he will inspire to encourage community participation in environmental preservation.

Schools that apply the principles of education for sustainable development as affirmed and modified in Adiwiyata as a model of environmental education in Indonesia, in general can educate their school community to take inspiration from environmental engineering designs that are found outside. Likewise the ability to produce innovative ideas to create technical tools and design a policy based on environmental management concepts, is higher.

In the future it is necessary to develop a new perspective on environmental education as an overall effort to put forward ways to inspire the public to know the need to protect the environment. This kind of environmental education will further enhance awareness of the environment in a wider field. Likewise, this education will inspire the public to find ways that can be done to realize these goals.

This new perspective on environmental education which is not only based on educational institutions will give new awareness to the public to get accustomed to knowing the reasons for an environmental engineering product or an environmental policy made. People who are accustomed to living in an environment that is designed to protect the natural resources in it, appear to be more aware and have the ability not to do activities that damage these natural resources. This can be seen from the traditional communities of indigenous tribes in various regions, such as the Bedouin, Kajang, and Anak Dalam tribes. Likewise, people in developed cities, such as cities in Japan, the Netherlands, Finland are automatically educated when looking at city tools that are designed to be environmentally friendly, as well as city rules made based on good environmental management systems.

Assume that environmental education is an activity that takes place only within educational institutions, has fatal weaknesses. Education which has been interpreted as an activity of knowledge transfer, changes in attitudes and behavior, and improvement of students' skills, contains two weaknesses at once. First, it separates the education process into one particular area. Similarly, it is said that this perspective seems to localize environmental education only in certain places, namely schools.

Second, limiting the subject of environmental education to only those who are studying in a school. This means that those who have graduated from the school are no longer required to carry out the mission of environmental education. Moreover, the general public, of course, feels 
not part of the mission of environmental education specifically and environmental preservation in general.

According to the characteristics of the environment, which contains diversity, there is a chain of interactions between the components in it, which describes the unity of living systems, requires harmony, shows interdependence, and requires sustainability, environmental education should also be interpreted as a living system as a whole. There are no components that must be separated from living systems in the dynamics of the environment. Thus, the localization of environmental education into educational institutions alone is tantamount to attracting and separating education and awareness from the community.

Such environmental education will foster a new culture in environmental preservation. The existence of a new culture is guaranteed to last in a longer period of time. That is, attitudes and behavior conscious of the environment as well as motivation and ability to innovate environmental protection and conservation can last a long time even can be passed on to the next generation.

Another thing that also determines is the individual character and cultural construction. Both can be in the form of the results of the inspirational education process earlier. As a summary of this argument, the following will display cultural positions in the context of individuals and society.

Table 2. Culture Position in Community; Individual and Community Compare

\begin{tabular}{lll}
\hline \multicolumn{1}{c}{ Aspect } & \multicolumn{1}{c}{ Individual } & \multicolumn{1}{c}{ Community } \\
\hline \multirow{2}{*}{ Spirit of values } & $\begin{array}{l}\text { Character of moral, } \\
\text { Individual believes, } \\
\text { Transformation process }\end{array}$ & $\begin{array}{l}\text { Culture, } \\
\text { Ideology, } \\
\end{array}$ \\
& Che ideals & $\begin{array}{l}\text { Social ideals } \\
\text { Construction of } \\
\text { Culture }\end{array}$ \\
\hline
\end{tabular}

Source: Hammada (2015)

Based on interviews conducted with informants in this research it is known that those who have a new awareness of the environment are generally inspired by the design of environmental engineering and management systems in certain places. On the other hand, those who have not been inspired by a physical engineering or environmental management can only know about the theory of environmental preservation but cannot develop cultural behavior for the preservation of the environment.

It seems that this perspective needs to be supported by a fairly basic paradigm shift. This change starts from the redefinition of the nature of the environment through a new basic principle of cosmology. An in-depth philosophical research is needed about the change in the way humans view the universe and the resources within it. Likewise about man and his role in space and time, place and time he lived, and the future of the universe and humans, as well as other creatures in it.

Environmental damage prevention program have been carry out by developing environmental techniques. Such engineering is indeed successful, but efforts to control the potential for environmental damage do not seem to considered. That means, if we only rely on technical aspects, there may still be negligence in the prevention of the environment. The occurrence of environmental damage will only addressed as an opportunity to get a project. Therefore, environmental prevention will be a high cost. 
It means we faced a problem on the environmental issues, for example, each product of environmental technology are not bring a message to the public conscious. Therefore, publics are observe the environmental technology as a technology as well. There are no design for a shifting perspectives and public awareness about environmental, especially in sustainable world. Publics do not find a learn by the environmental technic products, or environmental management policy.

\section{Conclusions}

Based on the discussion of the results of this research, it can be concluded that environmental education is a process of growing knowledge and awareness that can affect the emergence of changes in one's attitude and skills to protect and preserve the environment. The process is not only obtained from the learning space at the existing educational institutions, but the process of inspiration that is engineered in life in the form of physical environmental engineering and environmental management.

\section{Limitation of The Research}

This study should be able to see a quantitative relationship between certain variables, such as the number of schools with certified or the Adiwiyata Mandiri predicate with environmental awareness behavior in the surrounding community. Thus, we can find out whether there is a significant relationship between the environmentally conscious behavior of the community members and the number of Adiwiyata Mandiri predicated schools in their area.

\section{Acknowledgement}

Many Thanks and appreciation to Mr. Radjendra Hertasning, Dr. Judilherry Justam, Ir. Tajuddin Noer, Ir. Hasanuddin Deang, Agus Parenrengi, Ir. Fatahuddin Massinai, Dr. Syafrin Liputo, Mustamin Al-Mandari, Muliaman, and the Dana Mustadhafin Foundation, which helped fund research, and Sulton Ahmad Lubis, and friends who assisted with typing the manuscript. 


\section{References}

[1] Anonymous.: Our common future: World Commission on Environment and Development. Oxford University Press: Oxford UK (1987)

[2] ___. Panduan Adiwiyata; Sekolah Peduli dan Berbudaya Lingkungan 2011. KNLH-RI, Jakarta (2011)

[3 __.: Un Decade of Education for Sustainable Development (2005-2014). UNESCO. Retrieved February 13, 2009, from http://portal.unesco.org/education/en/ev.phpURL_ID=27234\&URL_DO=DO_TOPIC\&URL_SECTION=201.html. (2002)

[4] __. . Undang-Undang Republik Indonesia No. 32 Tahun 2009 Tentang Pengelolaan dan Perlindungan Lingkungan Hidup. Sekretariat DPR RI: Jakarta (2009)

[5] Bergen, S.D., et.al.: Design Principle for Ecological Engineering. Ecological Engineering Journal. Vol. 18, Issue 2. (2001)

[6] Bloom, B.S. ed. et al.: Taxonomy of Educational Objectives: Handbook 1, Cognitive Domain. New York: David McKay (1956)

[7] David, Thomas G.: Environmental Literacy. The School Review, Vol. 82, No. 4, Learning Environments, pp. 687-705. Chicago Journal. Chicago (1974)

[8] Dreyfus, D., A.: A Definition of The Scope of Environmental Management. Congress of US (1970)

[9] Goffman, P., M.: Ecological Thresholds: The Key to Successful Environmental Management or an Important Concept With No Practical Application? Ecosystem Journal. Vol. 9, Issue 1 (2006)

[10] Hammada, M.A.S.: Model Pendidikan untuk Pembangunan Berkelanjutan dengan Pemanfaatan Modal Sosial; Studi Atas Penerapan Konsep Adiwiyata pada Sekolah Peraih Adiwiyata Mandiri di DKI Jakarta, SIL UI, Jakarta (2015)

[11] Kawbe, M.: Education for Sustainable Development for Tokyo Bay: Developing a Practice Framework of University-Based Coastal. Journal Marine Police. Elsevier. Tokyo (2009)

[12] Moleong, J., L.: Metode Penelitian Kualitatif. Remaja Rosda Karya: Bandung (2007)

[13] Roth, Robert. E.: Fundamental Concept for Environmental management Education. Journal of Environmental Education, vol. 1, Num. 3, The University of Wisconsin, Madison (1970)

[14] Selman, P., \& Parker, J.: Citizenship, Civicness, and Social Capital in Local Agenda 21. The International Journal of Justice and Sustainability, Vol. 2 (2007)

[15] Semiawan, C., R.: Metodologi Penelitian Kualitatif. Grasindo: Jakarta (2010)

[16] Stapp, William B.: The Concept of Environmental Education. The Journal of Environmental Education, Vol. 1, Num. 1 (1969) 